\title{
Standardization of in-house Polymerase Chain Reaction for the Identification of Mycobacterium tuberculosis at the Reference Tropical Disease Hospital in the State of Goiás, Brazil
}

\author{
Márcia Alves Vasconcelos Rodrigues/ ${ }^{+}$, Álvaro Bisol Serafini, Marieta de Souza Pereira, \\ Thathiane Dias da Silva*, Marcelo Fouad Rabahi**, Suely Lemes de Alves***, \\ André Kipnis
}

\author{
Departamento de Microbiologia, Instituto de Patologia Tropical e Saúde Pública, Universidade Federal de Goiás, 74605-050 \\ Goiânia, GO, Brasil *Secretaria Estadual da Agricultura **Hospital de Doenças Tropicais, Secretaria Estadual de Saúde \\ ****aboratório Central, Goiânia, GO, Brasil
}

This study compares smear, growth in Lowenstein-Jensen medium, and in-house polymerase chain reaction $(P C R)$ techniques for the detection of Mycobacterium tuberculosis. A total of 72 specimens from 72 patients with clinical symptoms of tuberculosis, including 70 sputum and two bronchial aspirate samples, were tested in parallel by smear, culture, and in-house PCR techniques. From these, 48 (66.6\%) were negative by the 3 methods, 2 (2.8\%) were smear positive and negative by culture and in-house PCR, 11 (15.3\%) were both smear and culture negative, and in-house PCR positive, 7 (9.7\%) were positive by the 3 methods, 2 (2.8\%) were positive by smear and culture, and negative by PCR, 2 (2.8\%) were positive by culture and PCR, but smear negative. After the resolution of discrepancies in PCR results, the sensitivity and specificity for in-house PCR technique to M. tuberculosis relative to the culture, were $81.8 \%$ and $81.9 \%$, respectively. These results confirm that this method, in-house PCR, may be a sensitive and specific technique for M. tuberculosis detection, occurring in both positive and negative smear and negative cultures.

Key words: Mycobacterium tuberculosis - polymerase chain reaction - tuberculosis - culture - smear

The increased tuberculosis (TB) incidence and treatment drop-out rate, added to the appearance of multi-drug resistance prompted the World Health Organization (WHO) to consider TB as a worldwide urgency in 1993, and its control has again become a public health issue (Raviglione et al. 1995). According to this report at least 30 million people died from TB in the1990's (Dolin et al. 1994). It is estimated that one third of the world population, almost 2 billion people, is infected by Mycobacterium tuberculosis, and currently, approximately 8.8 million new cases and 1.6 million deaths are attributed to tuberculosis (WHO 2004).

In Brazil, TB prevalence in all clinical forms hit, in the year 2001, 71,080 cases, that is, 418.5/100.000 inhabitants. In the Center-West region of the country, there were 2341 cases, or 20.1/100.000 inhabitants, and the state of Goiás reported 1197 cases, or 23.92/100.000 inhabitants (Brasil 2002).

The TB diagnostic techniques currently used are slow and have sensitivities and specificities that need to be improved (CDC 1989). Although the presumptive diagnosis of TB may be obtained through clinical history and

Financial support: Funape (Brazilian Agency), proc. 66365 ${ }^{+}$Corresponding author. Fax: +55-62-202.12.36. E-mail: malves@iptsp.ufg.br

Received 14 November 2003

Accepted 13 May 2004 radiological findings, the final diagnosis still depends on smear and culture. The smear is an inexpensive and fast method, but presents low sensitivity and specificity since a minimum of 5000 bacilli are needed for a positive test. Although the culture is the reference test for diagnostic confirmation (Kox et al. 1994, Katila et al. 2000, Morán Moguel et al. 2000), it takes 4 to 8 weeks to reach a final result (Koneman et al. 1997).

The most promising technique for a fast diagnosis is based on the polymerase chain reaction (PCR), which is theoretically capable of detecting one copy of DNA of any cell (Bates 1979, Barnes \& Barrows 1993). Besides the high sensitivity and specificity, this technique can produce results in few hours, and is being used in the diagnosis of a number of infectious diseases (Kocagoz et al 1993).

The aim of this work was to evaluate a in-house PCR procedure by comparing it to smear and culture in patients with suspicious TB. In addition, to improve TB diagnosis in order to assist a rapid and reliable diagnosis of patients from public hospitals from the Center-West region in Brazil.

\section{MATERIALSAND METHODS}

Patients and clinical specimens - The analyzed samples were sputum and bronchial aspirates collected from TB suspected patients at the state reference center, Hospital of Tropical Diseases (HDT), Goiás, Brazil, and obtained according to the medical ethics conduct code, and approved by the ethical research committees of this hospital and the Federal University of Goiás. The clinical assessment included the patient's medical history, signs, 
symptoms, chest X-ray, pathology, and microbiology results, in addition to follow-up observations. All patients were from both sexes and none were human immunodeficiency virus type 1 infected or suffered from acquired immunodeficiency syndrome (AIDS). Patients with immunosuppression due to medications or radiotherapy are also excluded. Seventy-two samples were analyzed between March, 1999 and August, 2000. All samples were identified with patient's name and collection date, and sent to the Instituto de Patologia Tropical e Saúde Pública, of the Federal University of Goiás, to proceed with culture and molecular procedures.

Acid fast bacilli smear, culture and identification Samples were decontaminated by the sodium lauryl sulfate method, and concentrated by centrifugation $(13,000 \mathrm{x}$ $\mathrm{g}$ for $5 \mathrm{~min}$ ), examined by Ziehl-Neelsen staining, and inoculated at the same time in 2 tubes with LowensteinJensen medium slants (L-J) and another 2 with L-J plus thiophene-2-carboxilic acid hydrazide $(\mathrm{T} 2 \mathrm{H})$ and pnitrobenzoic acid (PNB). After weekly examination, the cultures that showed growth at $37^{\circ} \mathrm{C}$ for 2 months were submitted to colony counting, and to biochemical identification based on growth time, presence of inhibitors, pigment production with PNB and $\mathrm{T} 2 \mathrm{H}$, and niacin production (Brasil 1994).

Standardization of PCR technique - Dilutions (on the number 1 MacFarland scale) were made from a pure culture of $M$. tuberculosis, producing serial dilutions 1:2; $1: 4 ; 1: 8$; and 1:16. After, these dilutions were centrifugated and re-suspended with $100 \mu \mathrm{l}$ of lysis buffer $(50 \mathrm{mM}$ of Tris. $\mathrm{HCl}$ at $\mathrm{pH} 8.0 ; 50 \mathrm{mM}$ of $\mathrm{KCl} ; 2.5 \mathrm{mM}$ of $\mathrm{MgCl}_{2} ; 0.45 \%$ of Tween $20 ; 0.45 \%$ of Nonidet P40, and $100 \mu \mathrm{g} / \mathrm{ml}$ of proteinase K). Lysis was carried out by incubation at $56^{\circ} \mathrm{C}$ for $3 \mathrm{~h}$, with enzyme inactivation by incubation at $95^{\circ} \mathrm{C}$ for 15 $\mathrm{min}$. From each dilution $2 \mu \mathrm{l}$ were used for the PCR reaction to determine DNA detection sensibility of $M$. tuberculosis. The initial conditions for PCR were: $10 \mathrm{ng}$ of each primer, Taq polymerase reaction buffer with $1.5 \mathrm{mM}$ of $\mathrm{MgCl}_{2}$, and one unit (U) of TaqDNA polymerase. The thermal cycler (Gene-Ataq-PharmaciaÒ) was programmed to promote a first denaturation at $94^{\circ} \mathrm{C}$ for $1 \mathrm{~min}$, and then 35 cycles of denaturation temperature of $92^{\circ} \mathrm{C}$ for $1 \mathrm{~min}$, annealing temperature of $60^{\circ} \mathrm{C}$ for $1 \mathrm{~min}$, and extension at $72^{\circ} \mathrm{C}$ for $1 \mathrm{~min}$.

The primers (Gibco BRL, US) used in the DNA amplification were specific to the $h s p 65$ gene sequence of the members of M. tuberculosis complex. The pair of primer A and B (5'ACCAACGATGGTGTGTCCAT3' and 3' CTTGTCGAACCGCATACCCT5', respectively) amplify a $439 \mathrm{bp}$ fragment of $h s p 65$ gene. Next, a nested PCR was performed using primers pairs $\mathrm{C}$ and D (5'GAGATCGA GCTGGAGGATCC3' and 3'AGCTGCACCCCAAAG GTGTT5', respectively) to originate a $383 \mathrm{bp}$ fragment inside the 439 bp product (Totsch et al. 1996).

PCR products were analysed in $2 \%$ agarose, containing ethidium bromide $(1 \mathrm{mg} / \mathrm{ml})$, and visualized on a UV transilluminator to verify the production of 2 fragments of 439 and $383 \mathrm{bp}$, to the first and second PCR, respectively.

After the definition of maximum dilution of detectable DNA, the optimization of $\mathrm{MgCl}_{2}$ concentration was con- ducted by preparing different PCR tests from the minimum amplifiable dilution, with testing performed with 0.5 ; $1.0 ; 1.5 ; 2.0 ; 2.5 ; 3.0 ; 3.5$; and $4.0 \mathrm{mM}$ of $\mathrm{MgCl}_{2}$, for the first and second PCR procedures. Similarly, the most costeffective concentration of TaqDNA polymerase for 0.5 ; $1.0 ; 1.5$; and $2.0 \mathrm{U}$ was determined, using the best dilution of DNA and $\mathrm{MgCl}_{2}$ as described above.

All batches of PCR reactions performed contained the DNA obtained from the pure culture in the first stage as a positive control, a negative sample consisted of DNA obtained from the clinical material of one individual without TB clinical suspicion, as well as another negative control consisted of ultra pure water instead of DNA (Kox et al. 1994).

DNA extraction method from clinical specimen - A second aliquot from the decontaminated clinical sample was stored at $-20^{\circ} \mathrm{C}$ for ulterior DNA extraction. The samples were concentrated by centrifugation, re-suspended in $100 \mu \mathrm{l}$ of the same lysis buffer containing 100 $\mu \mathrm{g}$ of proteinase $\mathrm{K} / \mathrm{ml}$, and incubated for $3 \mathrm{~h}$ at $56^{\circ} \mathrm{C}$. After proteinase $\mathrm{K}$ inactivation by incubation at $95^{\circ} \mathrm{C}$ for 10 min, lysed aliquots of $2.5 \mu 1$ at $1 / 10$ were used in PCR tests (Folgueira et al. 1993) using the same conditions as determinated by the standardization of culture sample.

Added to all experiments were $100 \mathrm{ng}$ of DNA extracted from a $M$. tuberculosis strain cultured in L-J medium used as positive control, ultra pure water (MilliQ ${ }^{\circledR}$, Millipore Corp.) as a negative control, and a sample of DNA of Lambda bacteriophage as molecular mass marker (Amersham-Pharmacia Biotech ${ }^{\circledR}$ ) was also applied (Sambrook et al. 1989).

Determination of sensitivity and specificity - The sensitivity and specificity patterns of PCR compared to the M. tuberculosis culture in L-J medium were analysed and results evaluated in a 2 X 2 standard table (EPINFO v. 6.04).

\section{RESULTS}

The $\mathrm{MgCl}_{2}$ range used varied from $0 \mathrm{mM}$ to $4 \mathrm{mM}$, with $0.5 \mathrm{mM}$ increments with optimum amplification resulting from $2 \mathrm{mM}$. Subsequent reactions were made from a Taq polymerase buffer containing $\mathrm{Mg} 2.5 \mathrm{mM}$ in the final concentration (Fig. 1).

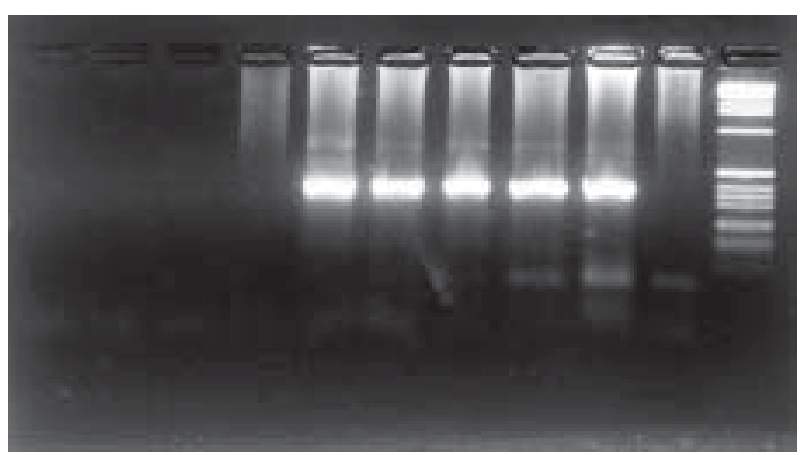

Fig. 1: concentration curve of magnesium for the determination of the optimum concentration. Band 1 to $9: 0 ; 0.5 ; 1.0 ; 1.5 ; 2.0 ; 2.5$; 3.0; 3.5; $4.0 \mathrm{mM} \mathrm{MgCl}$ respectively; 10: negative control (water), 11: $1 \mathrm{~kb}$ ladder marker (Amersham-Pharmacia Biotech ${ }^{\circledR}$ ) 
To determine the technique's sensitivity, control $M$. tuberculosis DNA with serial dilutions was used (Fig. 2), and the highest dilution where a visible amplification was obtained was $10^{-8}$, corresponding to a concentration of 1 $\mathrm{pg} / \mu \mathrm{l}$, and as $2 \mu \mathrm{l}$ per DNA reaction were used, the sensitivity limit was of $2 \mathrm{fg}$ of DNA. Although this sensitivity is very high, DNA extracted from the culture was used, which may present a different reality from the one found in the clinical samples due to the presence of interfering agents. From these results our positive control was used at $10^{-6}$ dilution $(0.1 \mathrm{pg} / \mu \mathrm{l})$.

The positive results for nested PCR of the samples from the patients with suspected TB (Fig. 3) show the amplification derived from the sputum samples with the

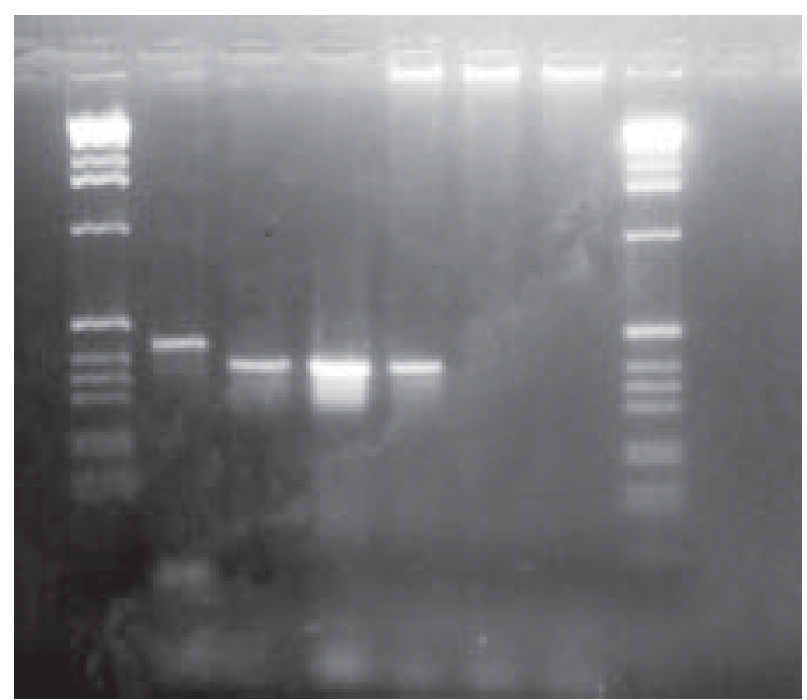

Fig. 2: determination of the detection sensitivity of Mycobacterium tuberculosis complex DNA. Band 1 and 7: $1 \mathrm{~kb}$ ladder marker (Amersham-Phamacia Biotech ${ }^{\circledR}$ ); 2 to 6 dilutions: $10^{-4} ; 10^{-6} ; 10^{-}$ $8 ; 10^{-10} ; 10^{-12}$, respectively; 8 : negative control (water)

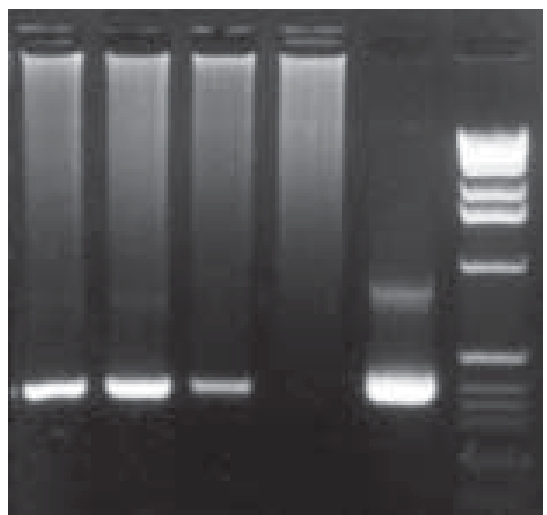

Fig. 3: result of the nested polymerase chain reaction of the $h s p 65$ gene of some clinical samples from acid fast bacilli positive patients (bands 1-3) and AFB negative by smear or culture, (band 4); band 5: positive control; band 6: 1 kb ladder marker (AmershamPhamacia Biotech $\left.{ }^{\circledR}\right)$

size of the amplified fragment after the nested PCR from the $h s p 65$ gene. In all three figures the arrow indicates the expected size of the amplified fragment after the nested PCR of this gene.

Our preliminary study of 72 respiratory specimens that included sputum and bronchial aspirates (Table I) from 72 patients showed that none of them were with antibiotic treatment. From these, 48 (66.6\%) were negative by smear, culture and PCR techniques, 2 (2.8\%) were smear positive and negative to both culture and PCR, $11(15.3 \%)$ were smear and culture negative and positive by PCR, 2 (2.8\%) were positive to smear and culture, but PCR negative, 2 $(2.8 \%)$ were smear negative and positive to culture and PCR, and 7 (9.7\%) were positive by the three methods.

The results provided a sensitivity of $81.8 \%$ (IC $95 \%$ : 47.7 - 96.8) and specificity of $81.9 \%$ (IC 95\%: 69.6 - 90.2) in relation to the culture (Table II).

TABLE I

Number of positive smear, culture, and polymerase chain reaction (PCR) samples of clinic specimens

\begin{tabular}{|c|c|c|c|c|c|c|c|}
\hline $\begin{array}{l}\text { Clinical } \\
\text { specimens }\end{array}$ & $\begin{array}{c}\text { Smear - } \\
\text { Culture - } \\
\text { PCR - }\end{array}$ & $\begin{array}{c}\text { Smear + } \\
\text { Culture - } \\
\text { PCR - }\end{array}$ & $\begin{array}{c}\text { Smear - } \\
\text { Culture - } \\
\text { PCR + }\end{array}$ & $\begin{array}{c}\text { Smear + } \\
\text { Culture + } \\
\text { PCR + }\end{array}$ & $\begin{array}{c}\text { Smear + } \\
\text { Culture + } \\
\text { PCR - }\end{array}$ & $\begin{array}{c}\text { Smear - } \\
\text { Culture + } \\
\text { PCR + }\end{array}$ & Total \\
\hline Sputum & 46 & 2 & 11 & 7 & 2 & 2 & 70 \\
\hline Bronchial aspirate & 2 & - & - & - & - & - & 2 \\
\hline Total & 48 & 2 & 11 & 7 & 2 & 2 & 72 \\
\hline
\end{tabular}

-: negative; +: positive

TABLE II

Comparison of polymerase chain reaction (PCR) results and those of the culture for detecting the Mycobacterium tuberculosis complex

Cultures with $M$. tuberculosis

\begin{tabular}{lcccc}
\cline { 2 - 3 } PCR reaction & Positive & Negative & Sensitivity (\%) & Specificity (\%) \\
\hline Total $\mathrm{n}=72$ & 9 & 11 & 81.8 & 81.9 \\
Positive & 2 & 50 & & \\
Negative & & & & \\
\hline
\end{tabular}




\section{DISCUSSION}

This study was conducted to validate a diagnostic protocol that we could use on AFB smear- and culturenegative specimens.

The observation of AFB in sputum samples or other biological material should be considered as TB suspected, but smear does not specifically identify M. tuberculosis. Moreover, this procedure is considered the least sensitive methodology for TB diagnosis because the estimated number of bacteria for positive smear is $10^{3}-10^{5} / \mathrm{ml}$ (Kent \& Kubica 1985, Forbes 1987, Brasil 1994). This justifies the negative smear result in two samples, in contrast with positive results in culture and PCR, which are more sensitive techniques (Morán Moguel et al. 2000).

Smear and culture showed negative results in 11 cases, while positive by PCR, probably due to the fact that the amount of mycobacteria present was not enough to be detected by these techniques, while the number for detection by PCR is in the order of 20 cells (Eisenach et al. 1990, Altamirano et a1. 1992) and in our own studies we could amplify from as low as one single bacterium in culture. Furthermore, the contamination of samples before, during, or after amplification could result in PCR positivity, while the conventional tests were negative (Kox et al. 1994, Morán Moguel et al. 2000), but we have ruled out this possibility with the inclusion of negative controls.

The 2 positive samples for smear and culture, with negative PCR, might have been developed by the fact that the protocol was specific to MTB complex, as well as the fact that the stain and the culture were not specific to the genus and species (Morán Moguel et al. 2000). On the other hand, the false-negative PCR result, in a negative smear sample and positive to $M$. tuberculosis in culture, could be explained by the presence of inhibitors of the amplifying system sample, that may be observed in $2.9 \%$ to $20 \%$ of the cases (Clarridge et al. 1993, Nolte et al. 1993, Burkardt 2000). Furthermore, these inhibitors were common in sputa samples, the same specimen where the PCR negative result was obtained in this study (Clarridge et al. 1993, Pfyffer et al. 1996). We have tried to ruled out PCR inhibitors by further diluting the samples that resulted negative in the PCR assay without any difference in results.

The PCR positive results may not necessarily reflect an active infection by $M$. tuberculosis because it is not possible to distinguish a previous infection from a minimum quantity of bacteria that does not have clinical significance and does not need treatment (Morán Moguel et al. 2000). Therefore, an approach to PCR positive results in asymptomatic patients, prior to considering them falsepositive, must first discard the possibility of sample contamination, look into the patient's clinical history or whether the patient is in treatment (Cousins et al. 1992, Kox et al. 1994).

Sensitivity of the culture is considered low when biological samples are analyzed with a small number of mycobacteria that must necessarily be viable to yield positive results (Eisenach et al. 1993). On the other hand, in this study, the only criterion for sample selection was TB suspicion in any of its forms, because it is probable that, if more specific clinical criteria are established for a sample for PCR, there will be a significant increase in positive results, mainly when negative smears occur (Kritski et al. 1997).

Therefore, the PCR protocol showed a better sensitivity and specificity to TB diagnosis than the culture. In addition it can be executed in less than $48 \mathrm{~h}$, making it possible to get faster results and minimizing the number of false-positive and -negative results (Cartuyvels et al. 1996, Morán Moguel et al. 2000). Finally, when negative PCR results display a discrepancy in relation to other clinical or laboratory criteria, the false-negative results should be discarded due to the presence of inhibitors, to the lack of any basic reaction component, to the use of inappropriate reagent concentrations, or to wrong temperatures (Eisenach et al. 1991, Clarridge et al. 1993).

The sensitivity $(81.8 \%)$ and specificity $(81.9 \%)$ of the PCR protocol used in this study is within the limits described by other authors for similar procedures $(60 \%$ to $100 \%$ ) (Beige et al. 1995, Moore \& Curry 1995, Su et al. 2000), although Lim et al. (2000) found a low sensitivity (44\%) and a similar specificity (99\%). Padilla et al. (2001), when using the PCR with reverse hybridization line-probe assay to Mycobacterium sp., obtained a sensitivity and specificity of $100 \%$.

Similarly, Mehrotra et al. (2002) developed an in-house PCR procedure, a less expensive method, for detection of M. tuberculosis in cytological specimens, and obtained the same results when compared to the Roche Amplicor kit. Kontos et al. (2003) identified all recovered cultured mycobacteria by a in-house molecular method.

In conclusion, our study shows that the PCR technique have advantages over AFB smear and culture for predicting diagnosis results in specimens containing a low number of organisms, and this situation could lead to earlier initiation of appropriate therapy and epidemiological intervention. The technique should be used together with the traditional methods of tuberculosis diagnosis until some of the technical limitations of this technique are solved.

\section{ACKNOWLEDGMENTS}

To Prof. LAM Bataus for his support in the investigation of some samples, to our dear colleague Prof. SA Silva for the statistic analysis, and Paulo Kol for critical review of the English version of the manuscript.

\section{REFERENCES}

Altamirano M, Kelly M, Wong A, Bessuille E, Black W, Smith J 1992. Characterization of a DNA probe for detection of Mycobacterium tuberculosis complex in clinical samples by polymerase chain reaction. J Clin Microbiol 30: 2173-2176.

Barnes PF, Barrows AS 1993. Tuberculosis in the 1990. Ann Intern Med 119: 400-410.

Bates HJ 1979. Diagnosis of tuberculosis. Chest 76: 757-763.

Beige J, Lokies J, Schaberg T, Finckh U, Fisher M, Mauch H, Lode H, Kohler B, Rolfs A 1995. Clinical evaluation of a Mycobacterium tuberculosis PCR assay. J Clin Microbiol 33: 90-95.

Brasil 1994. Manual de Bacteriologia da Tuberculose, Centro de Referência Professor Hélio Fraga, Fundação Nacional de Saúde, Ministério da Saúde, Rio de Janeiro, 115 pp.

Brasil 2002. Sistema Nacional de Vigilância Epidemiológica. 
Doenças de Notificação Compulsória - 1980-2001, Fundação Nacional de Saúde, Ministério da Saúde. Available in: www.funasa.gov.br/epi. Access: 26.09.2002.

Burkardt H 2000. Standardization and quality control of PCR analyses. Clin Chem Lab Med 38: 87-91.

Cartuyvels R, Ridder C, Jonckheere S, Verbist L, van Eldere J 1996. Prospective clinical evaluation of Amplicor Mycobacterium tuberculosis PCR test as a screening method in a low-prevalence population. J Clin Microbiol 34: 2001-2003.

CDC-Center for Disease Control and Prevention 1989. A strategic plan for the elimination for tuberculosis in the United States. MMWR 70: 281-285.

Clarridge J, Shawar R, Shinnick T, Plikaytis B 1993. Largescale use of polymerase chain reaction for detection of $M y$ cobacterium tuberculosis in a routine mycobacteriology laboratory. J Clin Microbiol 31: 2049-2056.

Cousins D, Wilton S, Francis B, Gow B 1992. Use of polymerase chain reaction for rapid diagnostic of tuberculosis. J Clin Microbiol 30: 255-258.

Dolin PJ, Raviglione MC, Kochi A 1994. Global tuberculosis incidence and mortality during 1900-2000. Bull WHO 72: 213-220.

Eisenach K, Cave M, Bates J, Crawford J 1990. Polymerase chain reaction amplification of a repetitive DNA sequence specific for Mycobacterium tuberculosis. J Infect Dis 161: 977-981.

Eisenach K, Cave M, Crawford J 1993. PCR detection of Mycobacterium tuberculosis. In D Persing, H Smith, F Tenover, T White (eds), Diagnostic Molecular Microbiology. Principles and Applications, American Society for Microbiology, Washington, DC, p. 191-196.

Eisenach K, Sifford M, Cave M, Bates J, Crawford J 1991. Detection of Mycobacterium tuberculosis in sputum samples using a polymerase chain reaction. Am Rev Resp Dis 144: 1160-1163.

Folgueira L, Delgado R, Palenque E, Noriega A 1993. Detection of Mycobacterium tuberculosis in clinical samples by using a simple lysis method and polymerase chain reaction. J Clin Microbiol 31: 1019-1021.

Forbes BA 1997. Critical assessment of gene amplification approaches on the tuberculosis. Immunol Invest 26: 105-116.

Katila ML, Katila P, Erkinjuntti-Pekkanen R 2000. Accelerated detection and identification of Mycobacteria with MGIT 960 and COBAS AMPLICOR Systems. J Clin Microbiol 38: 960-964.

Kent P, Kubica G 1985. Public Health Mycobacteriology: a Guide for the Level III Laboratory, Department of Health and Human Services, Centers for Disease Control, Atlanta, US, $280 \mathrm{pp}$.

Kocagoz T, Yilmaz E, Ozkara S, Kocagoz S, Hayran M, Sachedeva M, Chamber HF 1993. Detection of Mycobacterium tuberculosis in sputum samples by polymerase chain reaction using a simply field procedure. J Clin Microbiol 31: 1435-1438.

Koneman E, Allen D, Janda M, Schreckenberger P, Winn W 1997. Mycobacteria. In E Koneman, D Allen, M Janda, P Schreckenberger, W Winn (eds), Colour Atlas and Textbook of Diagnostic Microbiology, JB Lippincott Co., Philadelphia, p. 703-755.

Kontos F, Petinaki E, Nicolaou S, Gitti Z, Anagnostou S, Maniati M, Costopoulos C, Tselentis I, Maniatis A 2003. Multicenter evaluation of the fully automated Bactec MGIT 960 system and three molecular methods for the isolation and the identification of mycobacteria from clinical specimens. Diagn Microbiol Infect Dis 46: 299-301.

Kox L, Rhienthong D, Medo A, Udomsantisuk N, Ellis K, Leeuwen F, Heusden S, Kujiper S, Kolk A 1994. A more reliable PCR for detection of Mycobacterium tuberculosis in clinical samples. J Clin Microbiol 32: 672-678.

Kritski A, Rosseti M, Bonfim G, Castelo A, Mello F 1997. Reação em cadeia da polimerase (PCR) aplicada ao diagnóstico de tuberculose. J Pneumol 23: 33-42.

Lim TK, Gough A, Chin N, Kumarasinghe G 2000. Relationship between estimated pretest probability and accuracy of automated Mycobacterium tuberculosis assay in smear-negative pulmonary tuberculosis. Chest 118: 574-575.

Mehrotra R, Metz P, Kohlhepp S 2002. Comparison of inhouse polymerase chain reaction method with the Roche Amplicor technique for detection of Mycobacterium tuberculosis in cytological specimens. Diagn Cytophatol 26: 262265.

Moore D, Curry J 1995. Detection and identification of Mycobacterium tuberculosis directly from sputum sediments by Amplicor PCR. J Clin Microbiol 10: 2686-2691.

Morán Moguel M, Hernández D, de Oca PM, Arreola MP, Martínez SE, Fuentes H, Figuera L, Manzanares L, Corona J 2000. Detección de Mycobacterium tuberculosis mediante la reacción en cadena de la polimerasa en una poplación seleccionada del noroccidente de México. Rev Panam Salud Publica 7: 389-394.

Nolte F, Metchock B, MacGowan J, Edwards A, Okwumabua O, Thurmond C, Mitchell P, Plikaytis B, Shinnick T 1993. Direct detection of Mycobacterium tuberculosis in sputum by polymerase chain reaction and DNA hybridization. $J$ Clin Microbiol 31: 1777-1782.

Padilla E, Manterola J, Gonzalez V, Dominguez J, Matas Gali N, Ausina V 2001. Rapid detection of several mycobacterial species using a polymerase chain reaction reverse hybridisation assay. Eur J Clin Microbiol Infect Dis 20: 661-665.

Pfyffer G, Kissling P, Jhan E, Welscher H, Salfinger M, Weber R 1996. Diagnostic performance of amplified Mycobacterium tuberculosis direct test with cerebrospinal fluid, other nonrespiratory specimens, and respiratory specimens. $J$ Clin Microbiol 34: 834-841.

Raviglione M, Snider E, Kochi A 1995. Global epidemiology of tuberculosis. Morbidity and mortality of a worldwide epidemic. JAMA 273: 220-226.

Sambrook P, Fritsh E, Maniatis T 1989. Molecular Cloning - A Laboratory Manual, 2nd ed., vol. 1, Cold Spring Harbor Laboratory Press, New York, p. 6-15.

Su WJ, Tsou AP, Yang MH, Huang CY, Perng RP 2000. Clinical experience in using polymerase chain reaction for rapid diagnosis of pulmonary tuberculosis. Zhonghua Yi Xue Za Zhi 63: 521-526.

Totsch M, Bocker W, Brommelkamp E, Fille M, Kreczy A, Ofner D, Schmid K, Dockhorn-Dworniczak B 1996. Diagnostic value of different PCR assays for the detection of mycobacterial DNA in granulomatous lymphadenopathy. J Pathol 178: 221-226.

WHO-World Health Organization 2004. Global Tuberculosis Control-Surveillance, Planning, Financing, WHO Report 2004, Geneve, 226 pp. 
